\title{
Pengaruh Ekstrak Etanol Daun Kenikir (Cosmos caudatus) terhadap Kadar Glutathion Dan Interleukin 6 Serum Tikus Wistar Jantan yang Diberi Pakan Tinggi Kolesterol
}

\section{Effect of Ethanol Extract of Kenikir Leaf (Cosmos caudatus) on Glutathione and Interleukin-6 Serum of Male Wistar Rats that were given High Cholesterol Feed}

\author{
I Gusti Agung Dewi Sarihati ${ }^{1}$, I Gusti Ayu Sri Dhyanaputri ${ }^{2}$ \\ Jurusan Teknologi Laboratorium Medis, Politeknik Kesehatan Denpasar, Indonesia
}

\section{ARTICLE INFO}

\section{Article history:}

Received date

31 Dec 2019

Revised date

11 Mar 2020

28 Mar 2020

Accepted date

24 Apr 2020

Keywords:

GSH;

High cholesterol;

IL-6;

Kenikir leaves.

\section{Kata kunci:}

GSH;

Tinggi kolesterol;

IL-6;

Daun kenikir.

\author{
ABSTRACT/ ABSTRAK
}

Chronic dyslipidemia, especially in hypercholesterolemia, can directly disrupt endothelial cell function through increased formation of oxidized LDL which will stimulate an inflammatory response including interleukin 6 (IL-6) release. For this reason, it is necessary to have anti-inflammation that can reduce the effects of hypercholesterolemia on blood vessels. Polyphenols have anti-inflammatory effects and kenikir leaves are vegetables that are rich in polyphenols. This study aims to prove the effect of kenikir leaf (Cosmos caudatus) ethanol extract on IL-6 levels of serum of male Wistar rats fed high cholesterol. The method used is a true experimental study with a Post-test Only Control Group Design. Samples using 24 male rats were divided into 4 groups DS, DTK, Ss, and Cc. DTK, Ss and Cc groups were given high cholesterol feed for 20 weeks. In the 17th to 20th weeks the Ss group was given additional simvastatin and the Cc group was given an additional extract of Cosmos caudatus leaf. Whereas the DS group was only given standard feed for 20 weeks. After 20 weeks all rats in all four groups were examined serum GSH and IL-6 levels. The results showed the highest GSH serum levels average in Cc with pvalue $=0,016$ but not different from Ss. IL- 6 serum levels in DTK were higher than those of the other three groups and were significantly different with $\mathrm{p}$-value $=0,035$. The difference occurs between DTK and DS, Ss and Cc, not different between DS, Ss and Cc. The ethanol extract of kenikir leaf influences the serum IL-6 levels of male Wistar rats fed high cholesterol.

Dislipidemia kronis, terutama pada hiperkolesterol, dapat secara langsung mengganggu fungsi sel endotel melalui peningkatan pembentukan LDL teroksidasi yang akan merangsang respon inflamasi diantaranya terjadinya pengeluaran interleukin 6 (IL-6). Untuk itu diperlukan adanya antiiflamasi yang dapat mengurangi efek hiperkolesterol terhadap pembuluh darah. Polifenol memiliki efek antiiflamasi dan daun kenikir merupakan sayuran yang kaya akan polifenol. Tujuan penelitian membuktikan pengaruh ekstrak etanol daun kenikir terhadap kadar IL-6 serum tikus Wistar jantan yang diberi pakan tinggi kolesterol. Metode yang digunakan true experimental dengan rancangan Post-test Only Control Group Design. Sampel menggunakan 24 ekor tikus jantan yang dibagi menjadi 4 kelompok DS, DTK, Ss, dan Cc. Kelompok DTK, Ss dan Cc diberikan pakan tinggi kolesterol selama 20 minggu. Pada minggu ke 17 sampai dengan minggu ke 20 kelompok Ss diberi tambahan simvastatin dan kelompok Cc diberi tambahan ekstrak etanol daun kenikir. (Cosmos caudatus). Sedangkan kelompok DS hanya diberi pakan standar selama 20 minggu. Setelah 20 minggu semua tikus pada keempat kelompok diambil darahnya untuk diperiksa kadar GSH dan IL-6 serum. Hasil menunjukkan rerata kadar GSH serum paling tinggi pada Cc dengan $p$-value $=0,016$ tapi tidak berbeda dengan Ss. Kadar IL6 serum pada DTK lebih tinggi dibandingkan tiga kelompok lainnya dan berbeda bermakna dengan $p$-value $=0,035$. Perbedaan terjadi antara DTK dengan DS, Ss dan Cc, tidak berbeda antar DS, Ss dabn Cc. Disimpulkan ekstrak etanol daun kenikir berpengaruh terhadap kadar GSH dan IL-6 serum tikus Wistar jantan yang diberi pakan tinggi kolesterol.

Corresponding Author:

I Gusti Agung Dewi Sarihati

Jurusan Teknologi Laboratorium Medis Politeknik Kesehatan Denpasar, Indonesia

Email: dewisarihati@gmail.com 


\section{PENDAHULUAN}

Penyakit Kardiovaskular merupakan penyebab kematian utama di berbagai negara maju dan tampak adanya kecenderungan meningkat sebagai penyebab kematian di berbagai negara berkembang. Khususnya penyakit jantung koroner (PJK) adalah penyebab yang perlu mendapat perhatian yang lebih mendalam pada negara berkembang mengingat kemajuan ekonomi telah mengakibatkan pergeseran dari penyakit menular ke penyakit kardiovaskular sebagai penyebab kematian utama (Weber and Noels, 2011). PJK berhubungan dengan aterosklerosis dan dislipidemia (Hatma, 2012). Ketidakseimbangan metabolisme lipid dan tidak baiknya respon imun akan berlanjut dengan adanya inflamasi pada dinding pembuluh darah. Gangguan keseimbangan lipid dan respon imun akan mengakibatkan peningkatan aktivitas leukosit khususnya monosit dan homeostasis yang diatur oleh kemokin dan reseptornya. Reseptor ini memicu kaskade sinyal intraseluler kompleks yang merangsang produksi sitokin proinflamasi dan mediator inflamasi lainnya (Weber and Noels, 2011 ).

Kadar LDL yang tinggi pada dislipidemia akan diikuti oleh tingginya asam lemak tak jenuh jamak (PUFA/poly unsaturated fatty acid) yang merupakan sebagian besar asam lemak yang terikat pada LDL. PUFA sangat rentan terhadap oksidasi karena ikatan rangkapnya, yang dapat mengakibatkan tingginya LDL teroksidasi (OxLDL). LDL teroksidasi $(O x-L D)$, diidentifikasi sebagai pemicu cedera dan peradangan dengan peningkatan kelengketan dan aktifasi leukosit (terutama monosit) dan platelet yang disertai dengan produksi sitokin (Cesari, et al., 2003). IL6 merupakan sitokin pro inflamasi yang ditemuai pada inflamasi akut maupun kronis. Terkait dengan inflamasi pembuluh darah, IL-6 diproduksi oleh makrofag dan mempunyai efek lokal, yakni menginduksi molekul adhesion atau Interstitial Cell Adhesion Molecule (ICAM) pada endotel dan menarik neutrofil ke tempat cidera (Karnen dan Rengganis, 2009). Omoigui (2007) menghipotesiskan bahwa IL-6 memediasi teroksidasinya LDL menjadi $o x-L D L$. Inflamasi yang dimediasi IL-6 terlibat dalam gangguan yang berkaitan dengan aterosklerosis (Omoigui, 2007) dan IL-6 merupakan prediktor yang paling kuat PJK (Cesari et al., 2003).

PUFA dilindungi dari serangan ROS oleh antioksidan. Antioksidan merupakan senyawa yang dapat menghambat reaksi oksidasi dengan mengikat radikal bebas dan molekul yang sangat reaktif dan meningkatkan sistem imun (Salvayre, et al., 2006). Antioksidan dibedakan atas antioksidan endogen yang bersifat primer dan antioksidan eksogen atau eksternal yang umumnya berasal dari luar terutama dari makanan. Yang termasuk dalam antitoksidan eksogen ini antara lain vitamin $\mathrm{A}, \mathrm{E}$ dan $\mathrm{C}, \beta$ carotene, flavonoid dan polyphenol dan terpenoid. Antioksidan ini biasanya berfungsi sebagai radical scavenging antioxdants (Bahorun, et al., 2006).

Sistem pertahanan mengatur produksi dan eliminasi oksidan dan sangat penting dalam penanganan kerusakan yang terjadi selama proses stres oksidatif. Pertahanan melawan ROS meliputi scavenger enzimatik dan antioksidan yang diperoleh dari luar yaitu dari makanan. Scavenger utama terlibat dalam inaktivasi dan terminasi radikal oksigen bebas adalah SOD (Superoxide dismutase), katalase, dan sistem glutathione. Glutathione $(\gamma$ glutamylcysteinylglycine, GSH) merupakan antioksidan non enzimatik (Fouad T, 2010) yang dapat ditemukan pada hewan, tumbuhan, tanaman dan mikroorganisme, larut dalam air dan berada di dalam cytosol dari sel atau substrat larut dalam air lainnya dan disebut antioksidan mayor karena jumlahnya yang cukup besar di dalam sel (Kidd P, 1997). Flavonoid dan polifenol yang ditemukan dalam tanaman dapat meningkatkan produksi GSH melalui pengaruhnya terhadap ekspresi substrat yang diperlukan untuk sintesa glutathione seperti CT cystine antiporter, gamma-glutamylcysteine synthetase and glutathione synthase (Bahia, et al., 2008).

Daun kenikir (Cosmos caudatus) mempunyai kandungan senyawa fenolik, merupakan salah satu senyawa dalam daun kenikir yang mempunyai sifat antioksidan. Antioksidan merupakan senyawa yang berpotensi untuk melawan oksidan berbahaya yang dapat merusak sel tubuh. Ekstraksi senyawa fenolik daun kenikir dengan Pulse Electric Field (PEF) menggunakan variasi rasio bahan: pelarut 1:8, dan waktu pemaparan PEF selama 6 detik adalah $65.27 \mathrm{mg} \mathrm{GAE} / \mathrm{g}$ fw dan $70.74 \%$ (Izza, dkk., 2016).

Penelitian tentang manfaat daun kenikir (Cosmos caudatus) sebagai pengobatan hiperlipidemia telah dilakukan pada tikus yang diberikan makanan tinggi kolesterol dan diberikan etanol ekstrak daun kenikir $200 \mathrm{mg} / \mathrm{kg}$ berat badan yang dibandingkan dengan atorvastatin berat $35 \mathrm{mg} / \mathrm{kg}$ selama empat minggu. Tikus yang diberikan ekstrak daun kenikir menunjukkan penurunan signifikan trigliserida plasma kolesterol total, lipoprotein 
densitas rendah (LDL) dan peningkatan yang signifikan pada lipoprotein-kolesterol densitas tinggi (HDL) (Perumal, et al., 2014).

Penelitian ini bertujuan untuk membuktikan pengaruh ekstrak daun kenikir terhadap kadar gluthation (GSH) dan interleukin 6 (IL-6) serum tikus terkait peranan daun kenikir sebagai antioksidan dan antiinflamasi.

\section{METODE}

Pemeliharaan hewan coba dilakukan di Lab Animal Unit Unud, pemeriksaan GSH dan IL-6 menggunakan metode Elisa dilakukan di Laboratorium Mantra Medika Bali, daun kenikir didapat dari pasar Sanur dan pembuatan ekstrak daun kenikir dilakukan di laboratorium jurusan Teknologi Laboratorium Medik Poltekkes Denpasar. Penelitian dilakukan dari bulan Mei sampai dengan bulan Desember 2019.

Penelitian ini telah melewati kaji etik dan memperoleh Persetujuan Etik (Ethical Approval) dengan Nomor LB.02.03/EA/KEPK/0306.1/2019 oleh Komisi Etik Penelitian Kesehatan Politeknik Kesehatan Denpasar.

\section{Bahan}

Pemeriksaan GSH menggunakan Rat GSH Elisa Kit dan IL 6 menggunakan Rat interleukin 6 Elisa Kit, keduanya dari Bioassay Technology Laboratory.

\section{Pembuatan Ekstrak Daun Kenikir}

Daun kenikir segar yang didapat dari pasar Sanur, dicuci dan dikeringkan dengan dianginkan terhindar dari matahari langsung. Setelah kering daun kenikir ditumbuk menggunakan penggiling komersial, disaring sampai didapatkan bubuk halus yang siap diekstraksi. Daun kenikir diekstraksi dengan metode maserasi menggunakan ethanol 96\%. Bahan bubuk halus daun kenikir direndam dengan ethanol $96(1: 8)$ pada suhu kamar selama 72 jam, ekstrak kemudian disaring dengan kertas saring Whatman No1 dan pelarutnya diuapkan menggunakan rotary evaporator pada $60{ }^{\circ} \mathrm{C}$. Hasilnya yang kental disimpan pada lemari pendingin sebelum diberikan kepada tikus.

\section{Pembuatan pakan tinggi kolesterol}

Pakan tinggi kolesterol yang diberikan pada tikus percobaan, dibuat berdasarkan penelitian yang telah dilakukan oleh Muwarni, dkk (2006) dan sudah dimodifikasi yaitu pakan yang terdiri dari $50 \%$ pakan standar, 31,8\% terigu, $1 \%$ kolesterol, $0,2 \%$ asam kolat, $10 \%$ minyak babi, $2 \%$ otak babi, dan 5\% kuning telur. Semua bahan dicampur dan digiling kemudian dibentuk butiran-butiran kecil dan dikeringkan.

Metode yang digunakan dalam penelitian ini adalah penelitian eksperimen dengan rancangan Post-test Only Control Group Design. Sampel menggunakan 24 ekor tikus Wistar jantan yang dibagi menjadi 4 kelompok yaitu kelompok pakan standar (DS), kelompok pakan tinggi kolesterol (DTK), kelompok tikus yang diberi pakan tinggi kolesterol dan simvastatin $0,8 \mathrm{mg} / \mathrm{kgBB}$ (Ss), kelompok tikus yang diberi pakan tinggi kolesterol dan ekstrak etanol daun kenikir (Cosmos caudatus) 200mg/kg BB (Cc). Kelompok DTK, Ss dan Cc diberikan pakan tinggi kolesterol selama 20 minggu. Pada minggu ke 17 sampai dengan minggu ke 20 kelompok Ss diberi tambahan simvastatin dan kelompok Cc diberi tambahan ekstrak etanol daun kenikir (Cosmos caudatus). Sedangkan kelompok DS hanya diberi pakan standar selama 20 minggu. Setelah 20 minggu semua tikus pada keempat kelompok diperiksa kadar glutathion dan IL- 6 serum.

\section{HASIL}

\section{Kandungan Senyawa Aktif Ekstrak Etanol Daun Kenikir}

Kadar air simplisia daun kenikir sebanyak $3,95 \%$ dan dari 287gram simplisia dihasilkan 32gram ekstrak kental. Uji kualitatif menunjukkan bahwa ekstrak daun kenikir yang digunakan dalam penelitian ini mengandung senyawa aktif yaitu fenol, kuinon, flavonoid dan saponin seperti yang tertuang dalam Tabel 1 .

Tabel 1. Kandungan Senyawa Aktif
\begin{tabular}{lc}
\multicolumn{2}{c}{ Etanol Daun Kenikir } \\
\hline \multicolumn{1}{c}{ Senyawa Aktif } & Hasil \\
\hline Alkaloid & negatif \\
Fenol & positif \\
Tanin & negatif \\
Kuinon & positif \\
Flavonoid & positif \\
Saponin & positif \\
\hline
\end{tabular}

\section{Kadar Gluthation (GSH) Serum Tikus}

Rata-rata berat badan tikus di awal penelitian (0 minggu) adalah $155 \pm 5 \mathrm{~g}$ sedangkan di akhir penelitian paling tinggi yaitu $300 \mathrm{~g}$ ditemukan pada kelompok tikus DTK dan paling rendah dengan rata-rata berat badan $233 \mathrm{~g}$ pada kelompok Ss. Hasil Pengukuran kadar GSH serum tikus menunjukkan bahwa rata-rata kadar 
GSH serum tertinggi ditemukan pada kelompok Cc sedangkan yang terendah pada kelompok DTK. Hasil selengkapnya ditampilkan pada Tabel 2.

Tabel 2. Rata-rata, Kadar GSH Serum Tikus Wistar Jantan

\begin{tabular}{lr}
\hline $\begin{array}{l}\text { Kelompok } \\
\text { Perlakuan }\end{array}$ & \multicolumn{1}{c}{ Rata-rata } \\
\hline DS & $54,81 \pm 2,42$ \\
DTK & $50,15 \pm 1,29$ \\
Ss & $71,72 \pm 2,71$ \\
Cc & $86,42 \pm 1,25$ \\
\hline
\end{tabular}

\section{Perbandingan Rerata Kadar Glutathion (GSH) Serum Tikus Wistar Jantan}

Hasil pengukuran semua variabel berupa data numerik. Sebelum melakukan uji beda maka data diuji terlebih dahulu untuk menentukan normalitas dan homogenitasnya. Normalitas data diuji dengan Shapiro Wilk sedangkan homogenitas dengan Lavene test. Data pada semua variabel berdistribusi normal sehingga dilanjutkan dengan uji one way anova untuk melihat ada tidaknya perbedaan dalam kelompok variabel. Dilanjutkan dengan post hoc tests LSD.

Rerata kadar GSH serum kelompok tikus yang diberi pakan tinggi kolesterol dan ekstrak daun kenikir paling tinggi $(86,42 \mathrm{mg} / \mathrm{L})$ dibandingkan tiga kelompok lainnya dan rata-rata kadar paling rendah ditemukan pada kelompok tikus yang diberi pakan tinggi kolesterol saja (DTK) yaitu sebesar $50,15 \mathrm{mg} / \mathrm{L}$. Analisis data dengan one way anova memperlihatkan ada perbedaan yang bermakna antar kelompok dengan $p$-value 0,016 . Hal ini memberi petunjuk adanya pengaruh pemberian ekstrak daun kenikir terhadap kadar GSH serum tikus.

Post hoc tests dengan LSD menunjukkan bahwa perbedaan yang bermakna terjadi antara kelompok DS dengan Cc ( $p$-value 0,010) dan antara DTK dengan $\mathrm{Cc}$ (p-value 0,004). Hal tersebut menunjukkan bahwa ekstrak daun kenikir berpengaruh terhadap kadar GSH serum tikus yang diberi pakan tinggi kolesterol dimana kadarnya melebihi kelompok yang lain. Perbedaan rerata kadar GSH serum antar kelompok ditunjukkan pada Tabel 3.
Tabel 3. Perbedaan Rerata Kadar GSH Serum Tikus Antara Kelompok Perlakuan

\begin{tabular}{lcc}
\hline $\begin{array}{c}\text { Kelompok } \\
\text { Perlakuan }\end{array}$ & $\begin{array}{c}\boldsymbol{p} \text {-value } \\
\text { (LSD) }\end{array}$ & $\begin{array}{c}\boldsymbol{p} \text {-value } \\
\text { (one way } \\
\text { anova) }\end{array}$ \\
\hline DS dengan DTK & 0,693 & \\
DS dengan Ss & 0,161 & \\
DS dengan Cc & 0,010 & 0,016 \\
DTK dengan Ss & 0,078 & \\
DTK dengan Cc & 0,004 & \\
Ss dengan Cc & 0,183 & \\
\hline
\end{tabular}

\section{Kadar Interleukin 6 (IL-6) Serum}

Hasil Pengukuran kadar IL-6 serum tikus menunjukkan bahwa rata-rata kadar IL-6 serum tertinggi ditemukan pada kelompok DTK sedangkan yang terendah pada kelompok Ss. Hasil selengkapnya ditampilkan pada Tabel 4

Tabel 4. Rata-rata Kadar IL-6 Serum Tikus Jantan Wistar

\begin{tabular}{lc}
\hline Kelompok Perlakuan & Rata - rata \\
\hline DS & $1,47 \pm 0,44$ \\
DTK & $2,17 \pm 0,59$ \\
Ss & $1,31 \pm 0,35$ \\
Cc & $1,55 \pm 0,48$ \\
\hline
\end{tabular}

Perbandingan Rerata Kadar Interleukin 6 (IL6) Serum Tikus Wistar Jantan

Rerata kadar IL-6 serum kelompok tikus yang hanya diberi pakan tinggi kolesterol (DTK) paling tinggi $(2,17 \mathrm{ng} / \mathrm{L})$ dibandingkan tiga kelompok lainnya dan rata-rata kadar paling rendah ditemukan pada kelompok tikus yang diberi pakan tinggi kolesterol dan simvastatin (Ss) yaitu sebesar $1,31 \mathrm{ng} / \mathrm{L}$. Analisis data dengan one way anova memperlihatkan ada perbedaan yang bermakna antar kelompok dengan p-value 0,035 . Hal ini memberi petunjuk adanya pengaruh pemberian ekstrak daun kenikir terhadap kadar IL-6 serum tikus.

Post hoc tests dengan LSD menunjukkan bahwa perbedaan yang bermakna terjadi antara kelompok DS dengan DTK ( $p$-value 0,035), antara DTK dengan Ss ( $p$-value 0,011$)$ dan antara DTK dengan $\mathrm{Cc}$ ( $p$-value 0,013). Hal tersebut menunjukkan bahwa ekstrak etanol daun kenikir berpengaruh terhadap kadar IL-6 serum tikus yang diberi pakan tinggi kolesterol dimana kadarnya lebih rendah dari kelompok yang hanya diberi pakan tinggi kolesterol dan tidak berbeda dengan kelompok yang diberi sivastatin. Perbedaan rerata kadar IL-6 serum antara kelompok perlakuan ditunjukkan pada Tabel 5. 
Tabel 5. Perbedaan Rerata Kadar IL-6 Serum Tikus Antara Kelompok Perlakuam

\begin{tabular}{lcc}
\hline $\begin{array}{r}\text { Kelompok } \\
\text { Perlakuan }\end{array}$ & $\begin{array}{c}\text { p-value } \\
\text { (LSD) }\end{array}$ & $\begin{array}{c}\text { p-value (one } \\
\text { way anova) }\end{array}$ \\
\hline DS dengan DTK & 0,035 & \\
DS dengan Ss & 0,599 & \\
DS dengan Cc & 0,640 & 0,035 \\
DTK dengan Ss & 0,011 & \\
DTK dengan Cc & 0,013 & \\
Ss dengan Cc & 0,953 & \\
\hline
\end{tabular}

\section{PEMBAHASAN}

\section{Kandungan Senyawa Aktif Daun Kenikir}

Ekstrak etanol daun kenikir yang digunakan dalam penelitian ini mengandung fenol dan flavonoid yang merupakan bagian dari polifenol. Polifenol dapat diklasifikasikan ke dalam kelompok-kelompok yang berbeda meliputi asam fenolik, flavonoid, stilbenes, dan lignan (Pandey, \& Rizvi, 2009). Penelitian terkait menunjukkan bahwa dalam ekstrak daun kenikir (Cosmos caudatus) ditemukan polifenol sebanyak $65.27 \mathrm{mg} \mathrm{GAE} / \mathrm{g}$ fw (Izza, dkk., 2016). Ekstrak daun kenikir mengandung flavonoid sebanyak 4,33 $\mu \mathrm{g} / \mathrm{ml}$ (Wahyuni, dkk.,2018) dan kandungan senyawa flavonoid pada ekstrak kenikir didominasi oleh kuersetin dan kaempferol, yakni sebesar $\pm 60 \%$ dari total senyawa flavonoid pada ekstrak tersebut. Kuersetin yang terkandung lebih banyak yaitu $51,3 \mathrm{mg} / 100 \mathrm{~g}$ fw dibandingkan dengan kaempferol $0.903 \mathrm{mg} / 100 \mathrm{~g}$ fw (Andarwulan, et al., 2010).

\section{Pengaruh Ekstrak Etanol Daun Kenikir terhadap Kadar Glutathion (GSH) Serum Tikus Wistar Jantan yang diberi Pakan Tinggi Kolesterol}

Pemberian ekstrak daun kenikir dalam penelitian ini berpengaruh terhadap kadar GSH yang mana pada tikus yang mendapat ekstrak daun kenikir selama 4 minggu memiliki kadar GSH serum yang lebih tinggi dari kelompok tikus yang tidak mendapat ekstrak daun kenikir. Hal ini dihubungkan dengan kandungan flavonoid ekstrak daun kenikir. Penelitian terkait antioksidan menunjukkan bahwa flavonoid secara efektif digunakan sebagai suplemen untuk meningkatkan status antioksidan dan sistem kekebalan tubuh (Goliomytis, et al., 2014). Radikal bebas meningkat dengan meningkatnya konsumsi oksigen, dan dinetralkan oleh sistem pertahanan termasuk antioksidan enzimatik dan non-enzimatik. Enzim superoxide dismutase
(SOD) glutathione peroxidase (GSH-Px), glutathione-S-transferase (GST), dan glutathione reductase (GR), adalah antioksidan utama dari sistem enzimatik dan bekerja pada tingkat sel. Antioksidan non-enzimatik, GSH adalah buffer redoks intraseluler yang utama, dan berfungsi sebagai penangkap radikal bebas secara langsung, co-substrat untuk aktivitas GPx dan co-factor dari banyak enzim. Penurunan sistem pertahanan antioksidan non-enzimatik seluler utama akan meningkatkan kerentanan terhadap stres oksidatif (Iskender, et al., 2016). Flavonoid konsentrasi relatif rendah merangsang transkripsi gen khusus untuk sintesis GSH dalam sel (Moskaug, et al., 2005).

Kandungan senyawa flavonoid pada ekstrak kenikir didominasi oleh kuersetin (Wahyuni, et al.,2018). Kuersetin menyebabkan penurunan sementara dan kemudian pemulihan penuh konsentrasi GSH intraseluler. Penurunan awal kadar GSH bukan karena oksidasi menjadi GSSG, melainkan karena pembentukan konjugat kuersetin-glutathione. Sehingga kuersetin secara signifikan mempengaruhi kadar GSH (Li, et al., 2016). Satu tugas penting untuk glutathione seluler adalah mengikat radikal bebas dan peroksida yang dihasilkan selama respirasi seluler normal, apabila tidak diikat akan mengoksidasi protein, lipid, dan asam nukleat. Satu mekanisme yang terjadi untuk menetralkan kerusakan oksidatif melibatkan transaktivasi gen penyandi enzim yang berpartisipasi dalam metabolisme dan sintesis glutathione. Kuersetin meningkatkan kapasitas antioksidan tubuh dengan mengatur kadar GSH. Pada saat radikal bebas oksigen dihasilkan dalam tubuh, superoksida dismutase (SOD) dengan cepat menangkap $\mathrm{O}^{2-}$ dan mengubahnya menjadi $\mathrm{H}_{2} \mathrm{O}_{2}$. Enzim ini selanjutnya mengkatalisis dekomposisi $\mathrm{H}_{2} \mathrm{O}_{2}$ menjadi $\mathrm{H}_{2} \mathrm{O}$ tidak beracun. Reaksi ini membutuhkan GSH sebagai donor hidrogen. Penelitian pada hewan dan sel menemukan bahwa kuersetin menginduksi sintesis GSH (Kobori M, et a.l, 2015) Ketika kuercetin diberikan pada dosis tinggi, keseimbangan dinamis GSH (di bawah aksi GSH peroksidase) dipengaruhi sehingga $\mathrm{H}_{2} \mathrm{O}_{2}$ dikonversi menjadi $\mathrm{H}_{2} \mathrm{O}$ dan $\mathrm{GSH}$ dioksidasi menjadi GSSG (glutathione disulfide teroksidasi) (Xu, et al., 2019). 


\section{Pengaruh Ekstrak Etanol Daun Kenikir terhadap Kadar Interleukin 6 (IL-6) Serum Tikus Wistar Jantan yang diberi Pakan Tinggi Kolesterol}

Ekstrak etanol daun kenikir berpengaruh terhadap kadar IL-6 serum tikus yang diberi pakan tinggi kolesterol dimana kadarnya lebih rendah dari kelompok yang hanya diberi pakan tinggi kolesterol dan tidak berbeda dengan kelompok yang diberi simvastatin. Hal tersebut dihubungkan dengan kandungan polifenol dalam ekstrak daun kenikir sebagai anti inflamasi. Hasil ini serupa dengan penelitian tentang efek polifenol dalam anggur merah terhadap sitokin proinflamasi yang berkaitan dengan aterosklerosis pada manusia yang menunjukkan bahwa senyawa fenolik anggur merah menurunkan konsentrasi serum molekul adhesi interselular-1 (ICAM-1), E-selectin, dan IL-6 dan menghambat ekspresi antigen terkait fungsi limfosit 1 pada limfosit $\mathrm{T}$ dan reseptor makrofag1, yang menunjukkan bahwa fraksi polifenol bertanggung jawab untuk mengurangi peradangan (Chiva-Blanch, et al., 2012). Penelitian yang dilakukan oleh Liu, et al. (2017) terhadap tikus yang diberikan konsumsi polifenol teh menemukan bahwa polifenol teh dapat menurunkan kadar serum faktor-faktor proinflamasi (TNF- $\alpha$ : IL-1 $\beta$ dan IL-6).

Polifenol dalam ekstrak daun kenikir mengandung flavonoid yang didominasi oleh kuersetin yang dapat berperan sebagai anti inflamasi. Asupan diet yang mengandung kuersetin dan berkelanjutan akan terakumulasi dalam darah dan secara signifikan meningkatkan konsentrasi kuersetin dalam plasma (Koli, et al., 2010). Kuersetin mampu menghambat matriks metaloprotein, yang biasanya dihambat oleh inhibitor aktivator plasminogen 1 (PAI-1) dalam fibroblast kulit manusia. Produksi IL-6 yang dirangsang IL-1 dari sel mast diatur oleh jalur biokimia yang berbeda dari degranulasi yang diinduksi IgE, dan kuersetin dapat memblokir sekresi IL-6 dengan dua langkah transduksi sinyal kunci yang terlibat (Li, et al., 2016). Mekanisme efek anti-inflamasi kuersetin, belum diketahui dengan pasti. Diduga akibat pengaruhnya yang dapat menjadi penghambat bagi Cyclooxygenase-2 COX-2 dan Inducible nitric oxide synthase (iNOS), nuclear factor (NF)- $\mathrm{BB}$, Activator protein (AP)-1, atau mitogenactivated protein kinase (MAPK) (Hošek J., and Šmejkal K., 2015). Terhambatnya enzim-enzim ini akan memiliki dampak anti-inflamasi. Nitric oxide (NO), sebuah mediator proinflamasi yang disintesis oleh iNOS akibat reaksi oleh senyawa proinflamasi seperti lipopolysaccharides (LPS). Penelitian lain menunjukkan bahwa pretreatment dengan kuersetin menghambat produksi iNOS dan NO yang diinduksi oleh LPS dan menangkal stres oksidatif yang diakibatkan oleh produksi NO yang tidak diregulasi (Angeloni, $\mathrm{C}$ and Hrelia, S (2012). Sementara itu, NF-кB dan AP1 , keduanya dihambat oleh kuersetin, merupakan fitur transkripsi yang signifikan dalam memodulasi sitokin proinflamasi (Qiao, Y., et al., 2016). Dalam sel endotel aorta tikus yang diinduksi glukosa tinggi masing-masing sebesar $43 \%$ dan 69\%, kuersetin $(100 \mu \mathrm{M})$ secara signifikan mengurangi produksi NF- $\kappa \mathrm{B}$ dan aktivitas AP-1 (Panicker, S.R., et al., 2010). Kuersetin kurang dari $10 \mu \mathrm{M}$ menghambat produksi NO, IL-6, monocyte chemoattractant protein-1 (MCP-1), Tumor necrosis factor$\alpha(\mathrm{TNF}-\alpha)$, iNOS, dan COX-2 dalam sel RAW 264.7 (Ramyaa, P., Krishnaswamy, R. and Padma, V. V., 2014). Kuersetin juga dapat menghambat sitokin proinflamasi. Pemberian kuersetin 150 miligram setiap hari salama enam minggu pada manusia secara signifikan menurunkan konsentrasi serum TNF- $\alpha$ (Egert, S., et al., 2009). Kuersetin (100-200mg/kg) juga terbukti mengurangi kerusakan histopatologis pankreas dan menurunkan tingkat mRNA dan protein NF- $\kappa B$, IL- $1 \beta$, IL- 6 , dan TNF- $\alpha$ pada pankreatitis akut terkait hipertrigliseridemia pada tikus (Zheng, J., et al., 2016).

Senyawa fenolik menghambat sekresi dan ekspresi sitokin proinflamasi. Penelitian tentang efek flavonoid pada sekresi sitokin, telah diamati bahwa apigenin, chrysin, diosmetin, kaempferol, luteolin, naringenin dan kuersetin, pada dosis 50 dan $100 \mathrm{nM}$ dapat mengurangi tingkat sekresi IL6 dan TNF- $\alpha$ dalam RAW 264.7 makrofag yang dipicu oleh LPS (Mueller M., Hobiger S., and Jungbauer A., 2010). Inkubasi sel ligamen periodontal manusia dengan apigenin $(40 \mu \mathrm{M})$ secara signifikan menurunkan produksi IL-1 $\beta$, TNF- $\alpha$, IL-6, dan IL-12 yang diinduksi nikotin dan LPS (Jeong G.S., et al., 2009). Selain itu, ditetapkan bahwa luteolin, kuersetin, genistein, kaempferol, apigenin, diosmetin dan hesperetin, pada 25 dan $50 \mu \mathrm{M}$, menghambat pelepasan TNF- $\alpha$ dalam makrofag yang diaktifkan LPS, kuersetin, luteolin dan genistein menjadi penghambat yang paling efisien dalam hal ini. sekresi sitokin. Lebih lanjut, kuersetin dan luteolin memberikan efek stimulasi pada ekspresi sitokin anti-inflamasi IL-10, tetapi pada konsentrasi rendah $(<50 \mu \mathrm{M})$ (Comalada M., et al., 2006). Kuersetin dan Luteolin, keduanya dengan dosis $25 \mu \mathrm{M}$, efektif menghambat produksi IL-1 $\beta$, IL- 6 , IFN- $\gamma$ dan TNF- $\alpha$ pada 
darah manusia yang diinkubasi dengan LPS (Ribeiro D., et al., 2015). Luteolin 8-C- $\beta$ fucopyranoside (LU8C-FP) yang terkandung dalam flavonoid gagal menghambat ekspresi IL$1 \beta$ dan IL-8, sehingga memberikan informasi yang mengarah pada penggunaan flavonoid ini untuk menanggulangi radang yang disebabkan oleh IL-6 (Lee Y.S., et al., 2015). seperti kolitis, diabetes, rheumatoid arthritis, kanker dan penyakit kardiovaskular.

NF- $\mathrm{BB}$ dan AP-1 adalah faktor transkripsi penting dalam modulasi mediator pro-inflamasi, seperti sitokin (Fujioka S., et al., 2004). Yang pertama memediasi ekspresi sitokin dan mediator inflamasi lainnya (Richmond A., and Yang J., 2016) sedangkan yang kedua berpartisipasi dalam sintesis molekul efektor dan sitokin selama respon imun bawaan (Qiao Y., et al., 2016) Karena peran penting NF- $\mathrm{KB}$ dan $\mathrm{AP}-1$ dalam peradangan, penelitian telah dilakukan untuk menentukan efek flavonoid dalam modulasi faktor transkripsi ini.

Simvastatin sebagai antiinflamasi dengan menghambat enzyme 3-hydroxy-3methylglutaryl-coenzyme A reductase (HMGR) yang berperan pada katalisis 3-hydroxy-3methylglutaryl co-enzyme A (HMG-CoA) menjadi mevalonat, yang mengakibatkan

\section{DAFTAR PUSTAKA}

Andarwulan, N., Batari, R., Sandrasari, D. A., Bolling, B., \& Wijaya, H. (2010). Flavonoid content and antioxidant activity of vegetables from Indonesia. Food chemistry, 121(4), 1231-1235. doi:10.1016/j.foodchem. 2010.01.033.

Angeloni, C and Hrelia, S (2012). Quercetin reduces inflammatory responses in LPSstimulated cardiomyoblasts. Oxidative Medicine and Cellular Longevity.

Bahia, P.K., Rattray, M., Williams, R.J., (2008). Dietary Flavonoid Epicatochin Stimulates Phosphatidylinositol 3-kinase-dependent Antioxidant Response Element Activity and Up regulates Glutathine in Cortical Astrocytes. Journal of Neurochemistry, 106 (5), pp: 2194-2204.

Bahorun T., Soobrattee, M.A.,LuximonRamma,V.,Arouma, O. (2006). Free Radicals and Antioxidants in Cardiovascular Health and Disease. Internet Journal of Medical Update, 1 (2), July-Des 2006. http://www. geocities.com.

Cesari, M., Penninx B.W., Newman, A.B., Kritchevsky, S.B., Nicklas, B.J., Sutton- berkurangnya mevalonat. Dengan dihambatnya pembentukan mevalonat oleh simvastatin maka akan mengurangi produksi IL-6 (Sakoda, et al., 2006). Polifenol ekstrak daun kenikir mengandung kaempferol yang merupakan bagian dari flavonoid. Kaempferol menunjukkan ikatan di tempat yang sama dengan statin yang menghambat HMG-CoA menjadi mevalonat. Karena jumlah dan posisi gugus $-\mathrm{OH}$ dari kaempferol membuatnya paling cocok untuk membentuk interaksi ikatan hidrogen pada tempat pengikatan substrat yaitu HMGR. Hal ini menunjukkan bahwa kaempferol dapat bertindak sebagai penghambat ikatan HMG-CoA pada enzim HMGR (Islam, dkk., 2015).

\section{SIMPULAN}

Ekstrak etanol daun kenikir (Cosmos caudatus) berpengaruh terhadap kadar GSH dan interleukin-6 (IL-6) serum darah tikus yang diberi pakan tinggi kolesterol. Kadar GSH serum lebih tinggi dan kadar IL-6 serum lebih rendah pada tikus yang mendapatkan ekstrak etanol daun kenikir dibandingkan dengan yang hanya diberi pakan tinggi kolesterol.

Tyrrell, K., Rubin, S.M., Ding, J., Simonsick, E.M., Harris, T.B., Pahor, M. (2003). Inflammatory markers and onset of cardiovascular events: results from the Health ABC study. Circulation 108(19): 2317-22.

Chiva-Blanch G1, Urpi-Sarda M, Llorach R, Rotches-Ribalta M, Guillén M, Casas R, Arranz S, Valderas-Martinez P, Portoles O, Corella D, Tinahones F, LamuelaRaventos RM, Andres-Lacuev. (2012). Differential effects of polyphenols and alcohol of red wine on the expression of adhesion molecules and inflammatory cytokines related to atherosclerosis: a randomized clinical trial. C, Estruch R. $J$ Clin Nutr Am, 95(2):326-34.

Comalada M., Ballester I., Bailón E., Sierra S., Xaus J., Gálvez J., de Medina F.S., Zarzuelo A. (2006). Inhibition of proinflammatory markers in primary bone marrow-derived mouse macrophages by naturally occurring flavonoids: Analysis of the structure-activity relationship. 
Biochem. Pharmacol. 72(8):1010-1021. https://doi.org/10.1016/j.bcp.2006.07.016

Egert, S., Bosy-Westphal, A., Seiberl, J., Kürbitz, C., Settler, U., Plachta-Danielzik, S., . . . Müller, M. (2009). Quercetin reduces systolic blood pressure and plasma oxidised low-density lipoprotein concentrations in overweight subjects with a high-cardiovascular disease risk phenotype: A double-blinded, placebocontrolled cross-over study. British Journal of Nutrition, 102(7), 1065-1074. doi:10.1017/S0007114509359127.

Fouad,T. (2010). Antioxidant Nature and Chemistry. http://www.doctorslounge.com.

Fujioka S., Niu J., Schmidt C., Sclabas G.M., Peng B., Uwagawa T., Li Z., Evans D.B., Abbruzzese J.L., Chiao P.J. (2004). NF-kB and AP-1 connection: Mechanism of NF$\kappa \mathrm{B}$-dependent regulation of AP-1 activity. Mol. Cell. Biol. ;24(17):78067819.

https://doi.org/10.1128/MCB.24.17.78067819.2004.

Goliomytis, M., Tsoureki, D., Simitzis, P. E., Charismiadou, M. A., Hager-Theodorides, A. L. Deligeorgis, S. G. (2014). The effects of kuersetin dietary supplementation on broiler growth performance, meat quality, and oxidative stability, Poultry Science, Volume 93, Issue 8, August 2014, Pages 19571962, https://doi.org/10.3382/ps.201303585

Hatma, R.D. (2012). Sosial Determinan Dan Faktor Risiko Kardiovaskuler (Analisa data sekunder Riskesdas 2007). Buletin Jendela Data dan Informasi Kesehatan, Smt II, 2012 : 13-21.

Hošek J., Šmejkal K. (2015). Flavonoids as Anti-inflammatory Agents. In: Parnham M. (eds) Encyclopedia of Inflammatory Diseases. Birkhäuser, Basel.

Iskender, $\mathrm{H}$, Yenice, $\mathrm{G}$, Dokumacioglu, E, Kaynar, O, Hayirli, A, \& Kaya, A. (2016). The Effects of Dietary Flavonoid Supplementation on the Antioxidant Status of Laying Hens. Brazilian Journal of Poultry Science, 18(4), 663668. https://dx.doi.org/10.1590/1806-90612016-0356

Islam, B., Sharma, C., Adem, A., Aburawi, E., \& Ojha, S. (2015). Insight into the mechanism of polyphenols on the activity of HMGR by molecular docking. Drug design, development and therapy, 9, 49434951. doi:10.2147/DDDT.S86705.
Izza, N, Dewi,S.R., Putranto, A.W., Yuneri, D.R., Dachi, MYS. (2016). Ekstraksi Senyawa Fenol Daun Kenikir (Cosmos Caudatus) Dengan Pulse Electric Field (Pef). Jurnal Teknologi Pertanian, Vol. 17 No. 2, 91-96.

http://jtp.ub.ac.id/index.php/jtp/article/dow nload/533/895.

Jeong G.S., Lee S.H., Jeong S.N., Kim Y.C., Kim E.C.(2009). Anti-inflammatory effects of apigenin on nicotine- and lipopolysaccharide-stimulated human periodontal ligament cells via heme oxygenase-1. Int. Immunopharmacol. 9 (12):1374-1380.

https://doi.org/10.1016/j.intimp.2009.08.015

Karnen, G.B., Rengganis, I. (2009). Imunologi Dasar. Jakarta: Fakultas Kedokteran Universitas Indonesia. p. 217-287.

Kidd, P.M. (1997). Glutathione: Systemic Protectant Against Oxidative and Free Radical Damage. Alternative Medicine Review. 2 (3).pp 155-176.

Kobori M., Takahashi Y., Akimoto Y., Sakurai M., Matsunaga I., Nishimuro H., Ippoushi K., Oike H., O.-K. M. (2015). Chronic high intake of kuersetin reduces oxidative stress and induces expression of the antioxidant enzymes in the liver and visceral adipose tissues in miceNo Title. $J$. Funct. Foods, 15, pp. 551-560. doi: doi: 10.1016/j.jff.2015.04.006.

Koli, R., Erlund, I., Jula, A., Marniemi, J., Mattila, P., \& Alfthan, G. 2010. Bioavailability of various polyphenols from a diet containing moderate amounts of berries. Journal of agricultural and food chemistry, 58(7), 3927-3932.

Lee Y.S., Kim M.S., Lee D.H., Kwon T.H., Song H.-H., Oh S.-R., Yoon D.Y. (2015). Luteolin 8-C- $\beta$-fucopyranoside downregulates IL-6 expression by inhibiting mapks and the NF- $\kappa B$ signaling pathway in human monocytic cells. Pharmacol. Rep. 67 (3):581587. https://doi.org/10.1016/j.pharep.2014.12.016

Li, C., Zhang, W. J., Choi, J., \& Frei, B. (2016). Kuersetin affects glutathione levels and redox ratio in human aortic endothelial cells not through oxidation but formation and cellular export of kuersetin-glutathione conjugates and upregulation of glutamatecysteine ligase. Redox biology, 9, 220-228. doi:10.1016/j.redox.2016.08.012.

Liu, L., Wu, X., Zhang, B., Yang, W., Li, D., Dong, Y., ... Chen, Q. (2017). Protective effects of tea polyphenols on exhaustive 
exercise-induced fatigue, inflammation and tissue damage. Food \& nutrition research, 61(1), 1333390. doi:10.1080/16546628.2017.1333390.

Moskaug, J., Carlsen,H., Myhrstad, M.C.W., Blomhoff, R. (2005). Polyphenols and glutathione synthesis regulation, The American Journal of Clinical Nutrition, Vol 81, Issue 1, January 2005, Pages 277S283S, https://doi.org/10.1093/ajcn/81.1.277S

Mueller M., Hobiger S., Jungbauer A.(2010) Anti-inflammatory activity of extracts from fruits, herbs and spices. Food Chem. ;122(4):987-996. https://doi.org/10.1016/j.foodchem.2010.03.041

Murwani,S., Ali, M., Muliartha, K. (2006). Diet Aterogenik Pada Tikus Putih (Rattus Novergicus Strain Wistar) Sebagai Model Hewan. Jurnal Kedokteran Brawijaya, XXII(1): 6-9

Pandey, K. B., \& Rizvi, S. I. 2009. Plant polyphenols as dietary antioxidants in human health and disease. Oxidative medicine and cellular longevity, 2(5), 270278. doi:10.4161/oxim.2.5.9498.

Omoigui, S. (2007). The Interleukin-6 Inflammation Pathway from Cholesterol to Aging-Role of Status, Bisphosphorates and plant polyphenols in Aging and Agerelated Diseases. Division of Inflamation and Pain Medicine, L.A. Pain Clinic, Los Angeles, USA. p. 31-33.

Panicker,S.R., Sreenivas,P., Babu, M. S., Karunagaran, D. and Kartha, C. C. (2010). Quercetin attenuates monocyte chemoattractant protein-1 gene expression in glucose primed aortic endothelial cells through NF- $\kappa \mathrm{B}$ and AP-1. Pharmacological Research, 62(4), 328-336. https://doi.org/10.1016/j.phrs.2010.06.003

Perumal, V., Hamid, A., Ismail, A., Saari, K., Abas, F., Ismail, I., ., M., Lajis, N., \& Khatib, A. (2014). Effect Of Cosmos Caudatus Kunth Leaves On The Lipid Profile Of A Hyperlipidemia-Induced Animal Model. Journal of Food Chemistry and Nutrition, 2(1), 43-51. Retrieved from http://escijournals.net/index.php/JFC N/article/view/450/290.

Qiao Y., He H., Jonsson P., Sinha I., Zhao C., Dahlman-Wright K. (2016). AP-1 is a key regulator of proinflammatory cytokine tnfamediated triple-negative breast cancer progression. J. Biol. Chem. 291(10): 5068-79. https://doi.org/10.1074/jbc.M115.702571

Ramyaa,P., Krishnaswamy, R. and Padma, V. V. (2014). Quercetin modulates OTA-induced oxidative stress and redox signalling in HepG2 cells-up regulation of Nrf2 expression and down regulation of NF- $\kappa \mathrm{B}$ and COX-2. Biochimica et Biophysica Acta (BBA)-General Subjects, 1840(1) 681-692.

https://doi.org/10.1016/j.bbagen.2013.10.0 24.

Ribeiro D., Freitas M., Tomé S.M., Silva A.M.S., Laufer S., Lima J.L.F.C., Fernandes E. (2015). Flavonoids inhibit COX-1 and COX-2 enzymes and cytokine/chemokine production in human whole blood. Inflammation; $\quad 38(2): 858-870$. https://doi.org/10.1007/s10753-014-9995-x Richmond A.,and Yang J. (2016) The role of $\mathrm{NF}-\kappa \mathrm{B}$ in modulating antitumor immunity. OncoImmunology. 5 (1):921. https://doi.org/10.1080/2162402X.2015.10 05522.

Sakoda, K., Yamamoto, M., Negishi, Y., Liao, J. K., Node, K., \& Izumi, Y. (2006). Simvastatin decreases IL-6 and IL-8 production in epithelial cells. Journal of dental research, 85(6), 520-523. doi:10.1177/154405910608500608.

Salvayre, A.N., Dousset, N., Ferretti, G., Bacchetti, T., Curalola, G., Salvayre, R. (2006). Antioxidant and Cytoprotective Properties of High- Density Lipoproteins in Vascular Cells. Free Radical Biology and Medicine Vol. 41 (7): 1031 - 1040.

Wahyuni, W.T., Darusman, L.K., Rahmat, A. P. (2018). Analisis Kadar Flavonoid Dan Antioksidan Ekstrak Daun Kenikir (Cosmos caudatus), Rumput Mutiara (Oldenlandia Corymbosa), Dan Sirsak (Annona Muricata) Dengan Teknik Spektrometri. Analit: Analytical and Environmental Chemistry, Volume 3, No. 01 .

Weber, C and Noels, H. (2011). Atherosclerosis: Current Pathogenesis and Theraupetic Options. Nature Medicine. Nov; 17 (11).1410-1422.

Xu, D., Hu, M. J., Wang, Y. Q., \& Cui, Y. L. (2019). Antioxidant Activities of Kuersetin and Its Complexes for Medicinal Application. Molecules (Basel, Switzerland), 24(6), 1123. doi:10.3390/molecules24061123.

Zheng, J., Wu, J., Chen, J. et al. (2016). Therapeutic effects of quercetin on early inflammation in hypertriglyceridemiarelated acute pancreatitis and its mechanism. Pancreatology, 16 (2), 200-210. https://doi.org/10.1016/j.pan.2016.01.005. 